\title{
Projective mapping: potential tool for sensory evaluation of coffees for industrial application
}

\section{Projective mapping: potencial ferramenta para avaliação sensorial de cafés para aplicação na indústria}

\author{
Lais Brito Cangussu ${ }^{1 *}$; Camila Gonçalves Rodrigues ${ }^{1}$; Milton Cosme Ribeiro ${ }^{1}$; \\ Victor Luiz Melo Dutra ${ }^{1}$; Erick Flávio Guimarães Amaral ${ }^{1}$; Camila Argenta Fante ${ }^{1}$
}

\section{Highlights:}

A sensory descriptive analysis of different coffee brands was performed.

Consumer preference for traditional and gourmet coffees was assessed.

Associations were found between roasting degree, composition and sensory properties.

\begin{abstract}
Sensory analysis is an important tool to control and improve the quality of food products. This study aimed to evaluate the sensory attributes and consumer preference of coffee beverages prepared from roasted ground coffee (Coffea arabica) of different brands sold in Minas Gerais, Brazil, using projective mapping and assess the relationship of sensory attributes and consumer preferences with physicochemical properties. Titratable acidity, $\mathrm{pH}$, soluble solids, color, crude fat, protein, total phenolic content, caffeine, trigonelline, 5-caffeoylquinic acid and caffeic acid were determined. Physicochemical properties showed good agreement with projective mapping data. Samples associated with high acidity in the projective mapping task had the highest levels of 5-caffeoylquinic acid. Coffees associated with bitter/roasted taste and darker colors had typical physicochemical characteristics and color properties of dark-roasted coffee. The sample perceived as thin had the lowest soluble solids content. Consumers preferred traditional, dark-roasted coffee over gourmet, light-roasted coffee. Projective mapping is an effective technique for assessing the sensory attributes of brewed coffee.
\end{abstract}

Key words: Acidity. Bitterness. Coffea arabica. Body. Quality.

\section{Resumo}

\begin{abstract}
A avaliação dos atributos sensoriais pode ser uma ferramenta importante para controlar e melhorar a qualidade de produtos alimentícios. Este trabalho teve como objetivo descrever sensorialmente amostras de café torrado e moído da espécie arábica de diferentes marcas brasileiras por teste descritivo avançado (projective mapping) e relacionar os dados obtidos com resultados físico-químicos. Foram analisados acidez titulável, $\mathrm{pH}$, sólidos solúveis, cor, lipídeos, proteínas, compostos fenólicos, cafeína, trigonelina, ácido 5-cafeoilquínico e ácido caféico. Os resultados obtidos nas análises físico-químicas foram coerentes com os atributos relacionados aos cafés no projective mapping. Os cafés agrupados no projective mapping próximos ao atributo acidez foram os que apresentaram os maiores valores de ácido 5-cafeoilquínico. Os cafés associados ao sabor amargo/torrado e cor concentrada apresentaram cor mais
\end{abstract}

\footnotetext{
' Programa de Pós-Graduação em Ciência de Alimentos, Universidade Federal de Minas Gerais, UFMG, Departamento de Alimentos, Belo Horizonte, MG, Brasil. E-mail: lai.sbc1@hotmail.com; camilagr.alimentos@gmail.com; miltoncribeiro@ gmail.com; victorluiz182@hotmail.com; erickfa@live.com; camilafante@ufmg.br

* Author for correspondence
} 
escura na análise colorimétrica e características físico-químicas de torrefação escura. O café considerado bebida diluída foi o que apresentou menor valor de sólidos solúveis. Os resultados mostraram que o projective mapping é eficiente para análises sensoriais descritivas de café e que o público testado tem preferência por cafés tradicionais com torrefação escura.

Palavras-chave: Acidez. Amargor. Coffea arabica. Corpo. Qualidade.

\section{Introduction}

Coffee is one of the most important commodities in the world. It is consumed by about one-third of the world's population and is a major agricultural export in several countries (Toschi, Cardenia, Bonaga, Mandrioli, \& Rodriguez-Estrada, 2014). Brazil is the largest coffee producer, followed by Vietnam, Colombia, Indonesia, Ethiopia and Honduras (International Coffee Organization [ICO], 2019). According to the International Coffee Organization (ICO), global coffee production increased by $5.7 \%$ in 2018 compared to the previous year, reaching $10,186,860 \mathrm{t}$, of which $3,750,000 \mathrm{t}$ was produced in Brazil (319,820 t for internal consumption and the remainder for exportation) (ICO, 2019). Coffea arabica, the oldest species cultivated for coffee production, has superior sensory quality and higher commercial value (Toschi et al., 2014).

Coffee is a complex beverage. The physicochemical composition of beans is a major determinant of coffee quality and is greatly influenced by the roasting process (Ribeiro, Ferreira, \& Salva, 2011). The Brazilian Official Classification (COB) separates coffee beans into three quality grades: traditional, superior and gourmet. Coffee beans are assigned a COB score according to the number and type of defects. The higher the score, the lower the quality. Traditional coffee has a COB score of 8 or lower and less than $20 \%(\mathrm{w} / \mathrm{w})$ of black, green and burned beans. Superior coffee has a COB score of 6 or lower, with less than $10 \%$ of black, green and burned beans. Green beans from previous harvests may be used in both traditional and superior coffees. Gourmet coffees, in contrast, have stricter requirements: Arabica coffee $(C$. arabica) beans, COB score of 2-4 and strictly soft, soft or barely soft flavor. Black, black-green, green, burned or fermented beans or beans from previous harvests cannot be used to produce gourmet coffee (Associação Brasileira da Indústria de Café [ABIC], 2004).

Descriptive approaches can provide valuable information about sensory quality. However, most descriptive methods involve the selection, training and maintenance of a panel of 8 to 15 assessors, requiring large amounts of time and resources. To overcome these limitations, researchers have developed alternative techniques. A less demanding but nevertheless powerful tool is projective mapping. Assessors are asked to arrange samples according to their similarities and differences so that similar samples are located near each other and different samples are placed far apart. This generates a sensory map in which each sample is represented by $x$ and $y$ coordinates. Assessors can also be asked to provide sensory descriptors for samples or groups of samples (Horita et al., 2017). This important tool deserves further investigation (Vicente et al., 2017). Projective mapping may provide relevant information for industries to control and improve coffee quality. This study aimed to assess the sensory quality of roasted ground Arabica coffees sold in Minas Gerais, Brazil, using projective mapping and investigate the relationship between coffee sensory properties and composition.

\section{Materials and Methods}

Six roasted ground $100 \%$ Arabica coffee products of four different brands sold in Minas Gerais, Brazil, were assessed: traditional and gourmet $\mathrm{A}$, traditional $\mathrm{B}$, traditional $\mathrm{C}$ and traditional and 
gourmet D. Experiments were carried out from May to June 2018 at the Federal University of Minas Gerais, Brazil.

Coffee beverages were prepared by pouring $1 \mathrm{~L}$ of water at $92-96{ }^{\circ} \mathrm{C}$ onto $100 \mathrm{~g}$ of ground coffee in a paper filter. Extracts were diluted to $0.01 \mathrm{~g} \mathrm{~mL}^{-1}$ and filtered through $0.2 \mu \mathrm{m}$ filters for chromatographic analysis and total phenolic content (TPC) determination.

Colorimetric analysis was performed on roasted ground coffee using a CM-2300d Konica Minolta colorimeter. Results are expressed as CIELab coordinates, $\mathrm{L}^{*}$ (lightness), a* (red-green value) and $\mathrm{b}^{*}$ (yellow-blue values). Chroma $\left(\mathrm{C}^{*}\right)$ and hue angle $\left(h^{\circ}\right)$ were calculated using Eqs. (1) and (2):

$$
\begin{aligned}
& C^{*}=\left[\left(a^{*}\right)^{2}+\left(b^{*}\right)^{2}\right]^{\frac{1}{2}} \\
& h^{\circ}=\tan ^{-1} \frac{b^{*}}{a^{*}}
\end{aligned}
$$

TPC was determined by the Folin-Ciocalteu method. Briefly, $1 \mathrm{~mL}$ aliquots of coffee extracts received the addition of $5 \mathrm{~mL}$ of Folin-Ciocalteu reagent $(10 \% \mathrm{w} / \mathrm{v})$ and $4 \mathrm{~mL}$ of sodium carbonate $(7.5 \% \mathrm{w} / \mathrm{v})$. A blank was prepared using $1 \mathrm{~mL}$ of distilled water instead of coffee extract (Morais, Aquino, Nascimento, Nascimento, \& Chang, 2009). Samples were left to rest for $90 \mathrm{~min}$ in the dark. Then, the absorbance was read at $765 \mathrm{~nm}$ using a UV-Vis spectrophotometer and a $10 \mathrm{~mm}$ thick glass cuvette. An analytical curve of gallic acid ( $>98 \%$, SigmaAldrich) was prepared. Results are expressed as mg gallic acid equivalents $100 \mathrm{~g}^{-1}$ sample.

Caffeine, trigonelline, 5-caffeoylquinic acid (5-CQA) and caffeic acid were quantified using a Prominence Shimadzu liquid chromatograph equipped with an automatic injector, a diode array detector $(272 \mathrm{~nm}$ for caffeine, $264 \mathrm{~nm}$ for trigonelline and $325 \mathrm{~nm}$ for 5-CQA and caffeic acid), a C18 reverse-phase column (Nucleosil, Shimadzu, $5 \mu \mathrm{m}$ particle size, $4.6 \mu \mathrm{m} \times 150 \mathrm{~mm}$ ) and a guard column (5 $\mu \mathrm{m}$ particle size). For caffeine and trigonelline, a gradient elution of 40:60 methanol/water was used at $1.0 \mathrm{~mL} \mathrm{~min}^{-1}$ and $25^{\circ} \mathrm{C}$ (Monteiro \& Trugo, 2005). Caffeic acid and 5-CQA were determined according to Belguidoum, AmiraGuebailia, Boulmokh and Houache (2014), with modifications. Separation was achieved by gradient

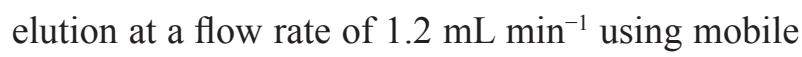
phase A (0.4\% phosphoric acid in 92.6:7 water/ acetonitrile) and mobile phase $\mathrm{B}(0.4 \%$ phosphoric acid in acetonitrile) at $50{ }^{\circ} \mathrm{C}$. Conditions were as follows: 0-8 $\mathrm{min}, 1-3 \% \mathrm{~B}$ (linear); 8-12 $\mathrm{min}, 3-8 \%$ $\mathrm{B}$ (linear); 12-15 min, 8-10\% B (linear); 15-20 min, 10-15\% B (linear); 20-25 min, 15-40\% B (linear); 25-30 min, 40-80\% B (linear); 30-35 min, 80-95\% B (linear); 35.0-35.1 min, 95-1\% B (linear) and 35.1-42 min, 1\% B. Compounds were identified by their retention times and spectra. Quantification was performed against analytical curves of caffeine (98\%, Sigma-Aldrich), trigonelline (95\%, Fluka), 5-CQA (95\%, Sigma-Aldrich) and caffeic acid (98\%, Sigma-Aldrich). Results are expressed as mg $100 \mathrm{~g}^{-1}$ sample.

Soluble solids ( ${ }^{\circ}$ Brix), titratable acidity and $\mathrm{pH}$ were determined in brewed coffee, according to Instituto Adolfo Lutz methods (Instituto Adolfo Lutz [IAL], 2004). Crude fat and protein contents were determined in ground coffee, the former by ether extraction according to Bligh and Dyer (1959) and the latter by the Kjeldahl method according to Association of Official Analytical Chemists [AOAC] (2005).

Analyses were performed in triplicate and the results presented as mean and standard deviation. Data were subjected to analysis of variance (ANOVA) followed by Tukey's test for pairwise comparisons. The level of significance was set at $p$ $<0.05$.

For sensory analysis, 12 assessors aged 19 to 42 years were selected through a questionnaire. Inclusion criteria were no aversion to coffee, not pregnant, willingness to participate in the sensory 
task, no restrictions on caffeine intake, good health, and frequent coffee consumption. Tasks were conducted individually, at room temperature. Samples $(20 \mathrm{~mL})$ were served at $80{ }^{\circ} \mathrm{C}$ in coded disposable plastic cups (MacFie, Bratchell, Greenhoff, \& Vallis, 1989). Assessors received a 50 $\times 70 \mathrm{~cm}$ sheet of paper and were instructed to place similar samples close to one another and different samples far from one another (Amyotte, Bowen, Banks, Rajcan, \& Somers, 2017). Then, they were asked to write the reasons for the arrangement. Traditional A and gourmet A coffees were served in duplicate to determine repeatability, totaling 8 samples. Sample positions were converted to $x$ and $y$ coordinates, data were subjected to correspondence analysis, and a sensory map was generated using R software.

A consumer preference test was conducted with 60 assessors aged 18 to 63 years. Six samples were served in random order, and participants were instructed to rank samples according to their preference. A completely randomized block design was used. Preference data were analyzed by the Friedman rank test using the Newell and MacFarlane table for interpretation of results. The level of significance was set at $p<0.05$.

This study was approved by the Research Ethics Committee (COEP) of the Universidade Federal de Minas Gerais, Brazil (protocol n. ${ }^{\circ}$ 2.718.992).

\section{Results and Discussion}

Assessors of the projective mapping task were mostly female $(58.33 \%)$. Their purchase intention was mainly influenced by quality ( $83.3 \%$ ), brand $(50 \%)$ and price $(50 \%)$. Figure 1 shows the correspondence analysis plot of projective mapping data. Differences were observed between and within coffee brands and grades (gourmet and traditional). Results of the physicochemical analyses, discussed in detail below, are in accordance with sensory parameters (Table 1).

Traditional A and B were more associated with coffee bitterness and density (Figure 1). These samples had characteristics of medium- to darkroasted coffee, such as high bitterness and dark color (Table 1). According to Campanha, Dias and Benassi (2010), coffee beans subjected to more severe temperature conditions are redder and darker, whereas beans processed under milder conditions are yellower and lighter. Gourmet $\mathrm{A}$ and $\mathrm{D}$ and traditional $\mathrm{C}$ and $\mathrm{D}$ had higher $\mathrm{L}^{*}$ values than traditional $\mathrm{A}$ and $\mathrm{B}$, indicating that the latter two had a higher roasting degree. All samples had $\mathrm{h}^{\circ}$ values greater than 45 , indicative of a predominance of yellow over red. Gourmet A had the highest $\mathrm{h}^{\circ}$ and $\mathrm{C}^{*}$ values, followed by gourmet $\mathrm{D}$, traditional $\mathrm{C}$ and traditional D. Traditional A and B had the lowest $\mathrm{h}^{\circ}$ and $\mathrm{C}^{*}$ values (Table 1). 


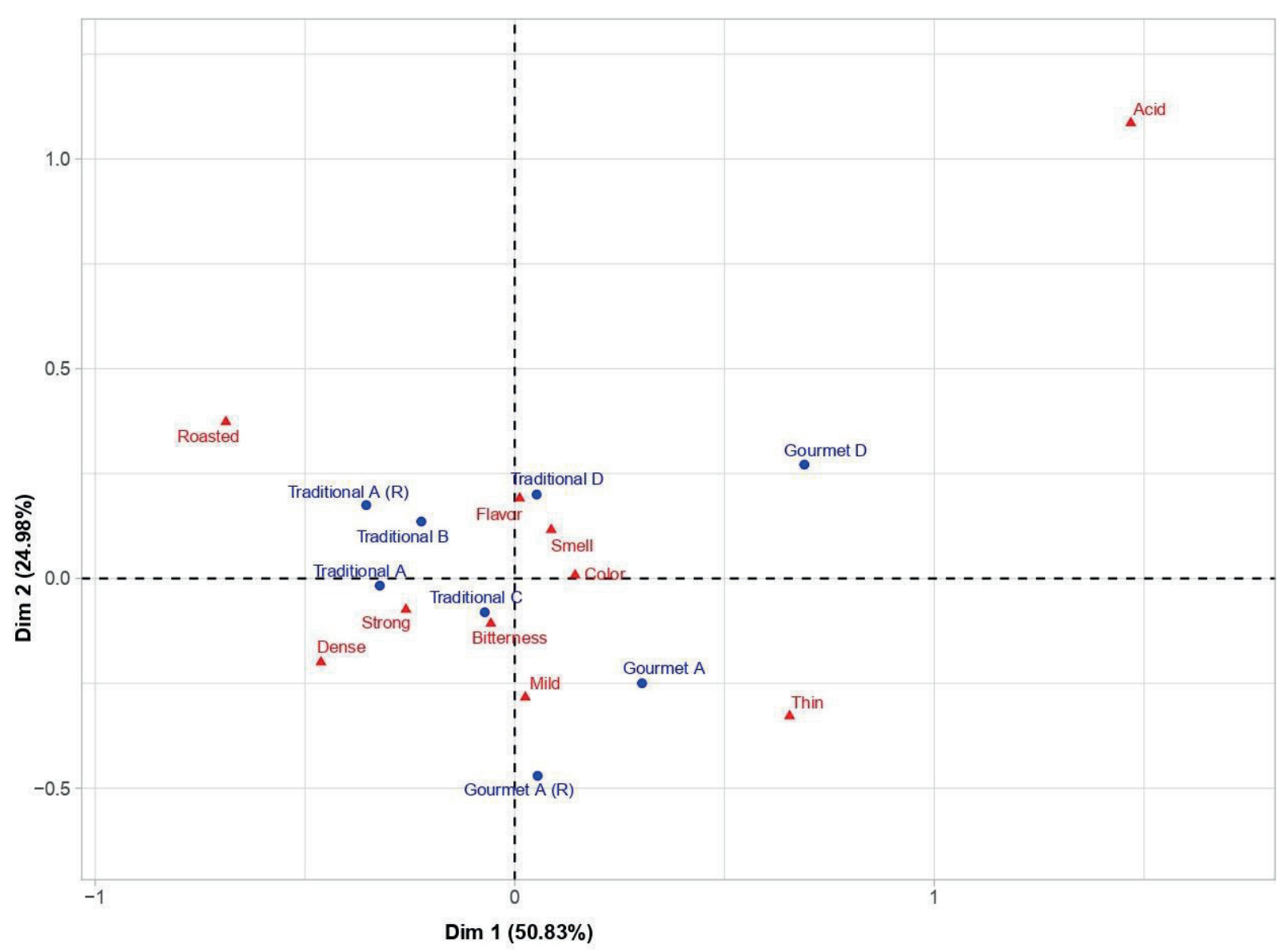

Figure 1. Correspondence analysis biplot of coffee samples (blue) and sensory descriptors (red), generated from projective mapping data.

Table 1

Color and physicochemical characteristics of traditional and gourmet coffees sold in Minas Gerais, Brazil

\begin{tabular}{|c|c|c|c|c|c|c|}
\hline \multirow[b]{2}{*}{ Variable } & \multicolumn{6}{|c|}{ Sample } \\
\hline & $\begin{array}{c}\text { Traditional } \\
\text { A }\end{array}$ & $\begin{array}{c}\text { Gourmet } \\
\text { A }\end{array}$ & $\begin{array}{c}\text { Traditional } \\
\text { B }\end{array}$ & $\begin{array}{c}\text { Traditional } \\
\text { C }\end{array}$ & $\begin{array}{c}\text { Traditional } \\
\text { D }\end{array}$ & $\begin{array}{c}\text { Gourmet } \\
\text { D }\end{array}$ \\
\hline $\begin{array}{l}\text { Chroma } \\
\left(\mathrm{C}^{*}\right)\end{array}$ & $\begin{array}{c}8.99 \\
\pm 0.15^{\mathrm{d}}\end{array}$ & $\begin{array}{c}20.77 \\
\pm 0.67^{\mathrm{e}}\end{array}$ & $\begin{array}{c}11.37 \\
\pm 0.13^{\mathrm{a}}\end{array}$ & $\begin{array}{c}15.95 \\
\pm 0.43^{\text {bc }}\end{array}$ & $\begin{array}{c}14.81 \\
\pm 0.43^{c}\end{array}$ & $\begin{array}{c}17.03 \\
\pm 0.35^{\mathrm{b}}\end{array}$ \\
\hline $\begin{array}{l}\text { Hue } \\
\left(\mathrm{h}^{\circ}\right)\end{array}$ & $\begin{array}{l}46.49 \\
\pm 0.45^{\mathrm{d}}\end{array}$ & $\begin{array}{l}56.50 \\
\pm 0.09^{\mathrm{e}}\end{array}$ & $\begin{array}{l}48.34 \\
\pm 0.09^{\mathrm{a}}\end{array}$ & $\begin{array}{l}51.74 \\
\pm 0.28^{\mathrm{b}}\end{array}$ & $\begin{array}{l}50.72 \\
\pm 0.51^{\mathrm{c}}\end{array}$ & $\begin{array}{l}51.09 \\
\pm 0.11^{\mathrm{bc}}\end{array}$ \\
\hline $\begin{array}{l}\text { Lightness } \\
\qquad\left(\mathrm{L}^{*}\right)\end{array}$ & $\begin{array}{l}11.98 \\
\pm 0.06^{\mathrm{a}}\end{array}$ & $\begin{array}{l}20.08 \\
\pm 1.14^{\mathrm{b}}\end{array}$ & $\begin{array}{c}13.77 \\
\pm 0.40^{\mathrm{a}}\end{array}$ & $\begin{aligned} & 17.65 \\
\pm & 1.80^{\mathrm{bc}}\end{aligned}$ & $\begin{array}{c}17.47 \\
\pm 0.14^{\mathrm{c}}\end{array}$ & $\begin{array}{l}18.83 \\
\pm 0.30^{\mathrm{bc}}\end{array}$ \\
\hline $\begin{array}{l}\text { Total phenolic content } \\
\qquad\left(\mathrm{mg} \text { GAE } 100 \mathrm{~g}^{-1}\right)\end{array}$ & $\begin{array}{l}1075.33 \\
\pm 42.23^{\mathrm{a}}\end{array}$ & $\begin{array}{l}1493.63 \\
\pm 54.77^{\mathrm{b}}\end{array}$ & $\begin{array}{l}1234.16 \\
\pm 88.74^{\mathrm{c}}\end{array}$ & $\begin{array}{l}1584.95 \\
\pm 69.74^{\mathrm{bd}}\end{array}$ & $\begin{array}{l}1495.35 \\
\pm 43.31^{\mathrm{b}}\end{array}$ & $\begin{array}{l}1655.23 \\
\pm 17.87^{\mathrm{d}}\end{array}$ \\
\hline $\begin{array}{l}\text { 5-Caffeoylquinic acid } \\
\qquad\left(\mathrm{mg} 100 \mathrm{~g}^{-1}\right)\end{array}$ & nd & $\begin{array}{c}149.34 \\
\pm 13.74^{\mathrm{a}}\end{array}$ & $\begin{array}{l}12.90 \\
\pm 3.35^{\mathrm{b}}\end{array}$ & $\begin{array}{l}142.53 \\
\pm 6.0^{\mathrm{a}}\end{array}$ & $\begin{array}{c}247.57 \\
\pm 14.51^{\mathrm{c}}\end{array}$ & $\begin{array}{c}353.57 \\
\pm 18.48^{\mathrm{d}}\end{array}$ \\
\hline
\end{tabular}


continuation

\begin{tabular}{|c|c|c|c|c|c|c|}
\hline $\begin{array}{l}\text { Caffeic acid } \\
\left(\mathrm{mg} 100 \mathrm{~g}^{-1}\right)\end{array}$ & nd & $\begin{array}{c}10.91 \\
\pm 1.50^{\mathrm{a}}\end{array}$ & nd & $\begin{array}{l}9.59 \\
\pm 0.99^{\mathrm{a}}\end{array}$ & $\begin{array}{c}30.04 \\
\pm 1.11^{\mathrm{b}}\end{array}$ & $\begin{array}{l}71.23 \\
\pm 6.36^{\mathrm{c}}\end{array}$ \\
\hline $\begin{array}{c}\text { Caffeine } \\
\left(\mathrm{mg} 100 \mathrm{~g}^{-1}\right)\end{array}$ & $\begin{array}{l}736.38 \\
\pm 21.57^{\mathrm{a}}\end{array}$ & $\begin{array}{l}1274.64 \\
\pm 66.04^{\mathrm{b}}\end{array}$ & $\begin{array}{l}859.44 \\
\pm 11.93^{\mathrm{a}}\end{array}$ & $\begin{array}{l}1215.05 \\
\pm 21.38^{\mathrm{b}}\end{array}$ & $\begin{array}{l}1148.59 \\
\pm 14.79^{\mathrm{b}}\end{array}$ & $\begin{array}{l}1262.04 \\
\pm 19.20^{\mathrm{b}}\end{array}$ \\
\hline $\begin{array}{l}\text { Trigonelline } \\
\left(\mathrm{mg} 100 \mathrm{~g}^{-1}\right)\end{array}$ & $\begin{aligned} & 7.56 \\
\pm & 1.51^{\mathrm{a}}\end{aligned}$ & $\begin{array}{l}244.82 \\
\pm 6.25^{b}\end{array}$ & $\begin{array}{l}35.20 \\
\pm 1.56^{\mathrm{c}}\end{array}$ & $\begin{array}{l}229.57 \\
\pm 9.14^{b}\end{array}$ & $\begin{array}{l}350.27 \\
\pm 1.26^{d}\end{array}$ & $\begin{array}{c}536.12 \\
\pm 16.41^{\mathrm{e}}\end{array}$ \\
\hline $\begin{array}{c}\text { Titratable acidity } \\
\left(\mathrm{mL} \mathrm{NaOH} 100 \mathrm{~g}^{-1}\right)\end{array}$ & $\begin{array}{c}86.58 \\
\pm 15.15^{\mathrm{a}}\end{array}$ & $\begin{array}{l}104.78 \\
\pm 17.86^{\mathrm{ab}}\end{array}$ & $\begin{array}{l}134.88 \\
\pm 4.99^{\mathrm{bc}}\end{array}$ & $\begin{array}{l}123.09 \\
\pm 17.58^{\mathrm{abc}}\end{array}$ & $\begin{array}{c}156.45 \\
\pm 15.12^{\mathrm{c}}\end{array}$ & $\begin{array}{c}302.95 \\
\pm 30.54^{\mathrm{d}}\end{array}$ \\
\hline $\mathrm{pH}$ & $\begin{aligned} & 7.55 \\
\pm & 0.04^{\mathrm{a}}\end{aligned}$ & $\begin{array}{c}6.54 \\
\pm 0.01^{\mathrm{b}}\end{array}$ & $\begin{array}{l}6.52 \\
\pm 0.06^{\mathrm{b}}\end{array}$ & $\begin{array}{c}6.31 \\
\pm 0.03^{\mathrm{c}}\end{array}$ & $\begin{array}{c}6.08 \\
\pm 0.01^{\mathrm{d}}\end{array}$ & $\begin{array}{c}4.91 \\
\pm 0.02^{\mathrm{e}}\end{array}$ \\
\hline $\begin{array}{l}\text { Soluble solids } \\
\quad\left({ }^{\circ} \text { Brix }\right)\end{array}$ & $\begin{array}{c}2.03 \\
\pm 0.05^{\mathrm{a}}\end{array}$ & $\begin{array}{l}1.10 \\
\pm 0.04^{\mathrm{b}}\end{array}$ & $\begin{array}{l}1.53 \\
\pm 0.06^{\mathrm{c}}\end{array}$ & $\begin{aligned} & 1.26 \\
\pm & 0.06^{\mathrm{d}}\end{aligned}$ & $\begin{array}{l}2.53 \\
\pm 0.06^{\mathrm{e}}\end{array}$ & $\begin{array}{c}2.37 \\
\pm 0.06^{\mathrm{f}}\end{array}$ \\
\hline $\begin{array}{l}\text { Proteins } \\
\left(\mathrm{g} 100 \mathrm{~g}^{-1}\right)\end{array}$ & $\begin{array}{c}16.04 \\
\pm 0.12^{\mathrm{a}}\end{array}$ & $\begin{array}{l}16.01 \\
\pm 0.16^{\mathrm{a}}\end{array}$ & $\begin{array}{l}15.90 \\
\pm 0.07^{\mathrm{a}}\end{array}$ & $\begin{array}{l}14.87 \\
\pm 0.61^{\mathrm{ab}}\end{array}$ & $\begin{array}{c}14.93 \\
\pm 0.72^{\mathrm{ab}}\end{array}$ & $\begin{array}{c}14.31 \\
\pm 0.56^{\mathrm{b}}\end{array}$ \\
\hline $\begin{array}{l}\text { Crude fat } \\
\left(\mathrm{g} 100 \mathrm{~g}^{-1}\right)\end{array}$ & $\begin{array}{c}18.59 \\
\pm 0.22^{\mathrm{a}}\end{array}$ & $\begin{array}{l}14.19 \\
\pm 0.12^{\mathrm{b}}\end{array}$ & $\begin{array}{l}18.45 \\
\pm 0.54^{\mathrm{a}}\end{array}$ & $\begin{array}{l}17.33 \\
\pm 0.19^{\mathrm{c}}\end{array}$ & $\begin{array}{c}14.57 \\
\pm 0.33^{\mathrm{b}}\end{array}$ & $\begin{array}{c}15.26 \\
\pm 0.19^{d}\end{array}$ \\
\hline
\end{tabular}

GAE, gallic acid equivalents; nd, not detected. Data are expressed as mean \pm standard deviation. Values within a column followed by different letters differ significantly $(\mathrm{p}<0.05)$.

Gourmet D had the highest concentration of total phenolic compounds, and traditional $\mathrm{A}$ and B had the lowest content (Table 1). Phenolics are degraded during the roasting process, resulting in the formation of pigments and volatile compounds (Conti, Kitzberger, Scholz, \& Prudencio, 2013). Therefore, the dark color of traditional $\mathrm{A}$ and $\mathrm{B}$ coffees agrees with their low total phenolic content.

Bitterness is desirable up to a certain level. This attribute increases with increasing roasting degree and time of extraction. Although caffeine, trigonelline and caffeic acid have a bitter taste, studies have shown that coffee bitterness stems from products of degradation of chlorogenic and caffeic acids, such as quinides and catechol oligomers (Blumberg, Frank, \& Hofmann, 2010).

Samples did not differ in caffeine content, except traditional A and B, which had lower caffeine levels (Table 1). Caffeine concentrations were similar to those reported by Perrone, Donangelo and Farah (2008) (843.3-1456.0 mg100 g $\mathrm{g}^{-1}$ ). Trigonelline, as well as caffeine, contributes greatly to coffee aroma. It reacts with other substances during roasting to form flavor compounds, such as furans, pyrazines, alkyl pyridines and pyrroles.

Trigonelline content differed between samples, except between gourmet $\mathrm{A}$ and traditional $\mathrm{C}$. Traditional A had the lowest content and gourmet $\mathrm{D}$, the highest. Trigonelline is rapidly degraded during roasting, and its concentration in roasted beans is inversely related to roasting time and temperature (Morais et al., 2009). These results indicate that gourmet D is light roasted, whereas traditional A and B are dark roasted. Trigonelline levels are in agreement with those found by Perrone et al. (2008) (279.7-955.7 mg100 $\mathrm{g}^{-1}$ ), excepting traditional A and $\mathrm{B}$, which had lower values.

Caffeic acid is formed by degradation of chlorogenic acid during roasting process, but it has low thermal stability and readily degrades at roasting temperatures (Morais et al., 2009). In this study, gourmet D had the highest concentration of caffeic acid. The compound was not detected in traditional $\mathrm{A}$ and $\mathrm{B}$ coffees. The findings indicate that traditional gourmet $\mathrm{A}$, traditional $\mathrm{C}$ and traditional $\mathrm{D}$ are medium roasted. Caffeic acid levels are in 
accordance with those reported by Belguidoum et al. (2014) (3.01-17.97 $\left.\mathrm{mg} 100 \mathrm{~g}^{-1}\right)$ and Morais et al.

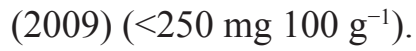

Traditional D and gourmet D were grouped closely together and were associated with acidity (Figure 1). This result is in agreement with 5-CQA levels (highest in gourmet D, followed by traditional D; Table 1). 5-CQA is associated with coffee acidity and bitterness (Shan, Suzuki, Suhandy, Ogawa, \& Kondo, 2014). Acidity is a very important flavor attribute. Generally, high-quality coffee has pronounced acidity, being classified as bright or tangy (Martinez, Poltronieri, Farah, \& Perrone, 2013). 5-CQA levels did not differ between gourmet $\mathrm{A}$ and traditional $\mathrm{C}$ but varied between other samples. Gourmet D showed the highest 5-CQA concentration, similar to those reported in a study by Abrahão, Pereira, Lima, Ferreira and Malta (2008) (370-380 mg $100 \mathrm{~g}^{-1}$ ). The authors observed that 5-CQA levels were lower after roasting. Traditional A and B coffees had the lowest content of 5-CQA. As discussed by Teixeira, Passos and Mendes (2016), beans subjected to severe roasting conditions produce coffee with lower acidity because of chlorogenic acid degradation.

Gourmet D had the highest titratable acidity, indicating superior quality (Martinez et al., 2013). The results were similar to those presented by Carvalho, Chagas, Chalfoun, Botrel and Juste Júnior (1994) (75-350 mL NaOH 100g-1). Acidity is also correlated with $\mathrm{pH}$. Samples differed in $\mathrm{pH}$, except gourmet A and traditional B. According to Lima, Lucia, Saraiva and Lima (2015), consumer acceptance is highly associated with coffee beverage $\mathrm{pH}$. The ideal $\mathrm{pH}$ range is 4.95 to 5.20. In this study, coffee samples had higher or lower (gourmet D) $\mathrm{pH}$ values than the ideal range.

Gourmet A was considered thin by assessors. This is explained by its low soluble solids content. Body is a measure of the coffee's thickness or the tactile perception of coffee beverage in the mouth. Sugars, proteins and lipids play a major role in coffee consistency and richness (Table 1). Gourmet $\mathrm{D}$ and traditional D had the highest levels of soluble solids, indicating that they were full-bodied. Sugar content depends on genetic variability, roasting degree, production site and storage conditions (Kitzberger, Scholz, Pereira, \& Benassi, 2013). Coffee samples did not differ in protein content; the results were similar to those of Conti et al. (2013) (14.31-16.91\%). Traditional A and B samples did not differ in lipid level, nor did gourmet $A$ and traditional D. Lipid content increases with roasting degree, as lipids, unlike other compounds, are not degraded during processing (Dias, Faria-Machado, Mercadante, Bragagnolo, \& Benassi, 2014). Accordingly, traditional A and B coffees had lower levels of bioactive compounds (TPC, caffeine, trigonelline, caffeine and 5-CQA) but higher crude fat content. Although proteins and lipids contribute to coffee body, no relationships were found between their levels and projective mapping data.

The preference test panel was composed mostly of women $(63.33 \%)$. Participants reported prioritizing quality $(90 \%)$ and price $(56.7 \%)$ when buying coffee. Table 2 shows the rank sum of each sample; higher values represent lower preference. Gourmet A and traditional $\mathrm{D}$ had the lowest values, differing significantly from gourmet D. The results show that consumers preferred traditional over gourmet coffee. Gourmet A had similar physicochemical characteristics to traditional samples and was the second-preferred coffee. Gourmet coffee typically has higher acidity and less bitterness than traditional coffee, as observed in gourmet D. Traditional D and gourmet A had similar crude fat and total phenolic contents, which might have contributed to consumer preference. These samples had the lowest crude fat levels, indicating that lipids contribute negatively to the sensory quality of coffee. This is probably due to the autoxidation of lipids. Traditional D and gourmet A had intermediate TPC, a parameter that is directly affected by roasting degree. 
Table 2

Consumer preference for different brands of coffee sold in Minas Gerais, Brazil

\begin{tabular}{lc}
\hline Sample & Rank sum \\
\hline Traditional A & $228^{\mathrm{abc}}$ \\
Gourmet A & $174^{\mathrm{cd}}$ \\
Traditional B & $222^{2^{\mathrm{abc}}}$ \\
Traditional C & $219^{\mathrm{abc}}$ \\
Traditional D & $171^{\mathrm{d}}$ \\
Gourmet D & $241^{\mathrm{a}}$ \\
\hline
\end{tabular}

Values followed by different letters differ significantly $(\mathrm{p}<0.05)$ by the Friedman test.

\section{Conclusions}

The sensory attributes of brewed coffee were successfully evaluated using projective mapping. Relationships were found between projective mapping data and physicochemical parameters. Acidity was associated with 5-CQA levels, body with soluble solids content, bitterness with bioactive compounds contents (caffeine, trigonelline, TPC, 5-CQA and caffeic acid contents) and undesirable sensory attributes with crude fat content. Although acidity is considered an important quality attribute, consumers had a low preference for high-acidity coffee.

\section{Acknowledgements}

The authors thank the Brazilian Federal Agency for Support and Evaluation of Graduate Education (CAPES) and the Minas Gerais Research Foundation (FAPEMIG) for the financial support.

\section{References}

Abrahão, S. A., Pereira, R. G. F. A., Lima, A. R., Ferreira, E. B., \& Malta, M. R. (2008). Compostos bioativos em café integral e descafeinado e qualidade sensorial da bebida. Pesquisa Agropecuária Brasileira, 43(12), 1799-1804. doi: 10.1590/S0100204X2008001200022
Amyotte, B., Bowen, A. J., Banks, T., Rajcan, I., \& Somers, D. J. (2017). Mapping the sensory perception of apple using descriptive sensory evaluation in a genome wide association study. Plos One, 12(2), 1-25. doi: 10.1371/journal.pone.0171710

Associação Brasileira da Indústria de Café (2004). Norma de qualidade recomendável e boas práticas de fabricação de cafés torrados em grão e cafés torrados e moídos. Recuperado de http://abic.com. br/src/uploads/2017/07/2.8.1-Norma-de-qualidadePQC.pdf

Association of Official Analytical Chemists (2005). Official methods of analysis. (18nd ed.). Washington: Association of Official Analytical Chemists.

Belguidoum, K., Amira-Guebailia, H., Boulmokh, Y., \& Houache, O. (2014). HPLC coupled to UV-Vis detection for quantitative determination of phenolic compounds and caffeine in different brands of coffee in the Algerian market. Journal of the Taiwan Institute of Chemical Engineers, 45(4), 1314-1320. doi: 10.1016/j.jtice.2014.03.014

Bligh, E. G., \& Dyer, W. J. (1959). A rapid method of total lipid extraction and purification. Canadian Journal of Biochemistry and Physiology, 37(8), 911917. doi: 10.1139/059-099

Blumberg, S., Frank, O., \& Hofmann, T. (2010). Quantitative studies on the influence of the bean roasting parameters and hot water percolation on the concentrations of bitter comdopounds in coffee brew. Journal of Agricultural and Food Chemistry, 58(6), 3720-3728. doi: 10.1021/jf9044606

Campanha, F. G., Dias, R. C. E., \& Benassi, M. T. (2010). Discriminação de espécie de café por caveol e cafestol: influência da torra e dos defeitos. Coffee Science, 5(1), 87-96. doi: 10.25186/cs.v5i1.265 
Carvalho, V. D., Chagas, S. J. R., Chalfoun, S. M., Botrel, N., \& Juste, E. S. G. Jr. (1994). Relação entre a composição físico-química e química do grão beneficiado e a qualidade de bebida do café. Pesquisa Agropecuária Brasileira, 29(3), 449-454.

Conti, M. C. M. D., Kitzberger, C. S. G., Scholz, M. B. S., \& Prudencio, S. H. (2013). Características físicas e químicas de cafés torrados e moídos exóticos e convencionais. Boletim Centro de Pesquisa de Processamento de Alimentos, 31(1), 161-172. doi: 10.5380/cep.v31i1.32720

Dias, R. C. E., Faria-Machado, A. F., Mercadante, A. Z., Bragagnolo, N., \& Benassi, M. T. (2014). Roasting process affects the profile of diterpenes in coffee. European Food Research and Technology, 239(6), 961-970. doi: 10.1007/s00217-014-2293-X

Horita, C. N., Esmerino, E. A., Vidal, V. A. S., Farah, J. S., Amaral, G. V., Bolini, H. M. A., Cruz, A. G., Pollonio, M. A. R. (2017).Sensory profiling of low sodium frankfurter containing garlic products: adequacy of polarized projective mapping compared with trained panel. Meat Science, 131, 90-98. doi: 10.1016/j.meatsci.2017.05.002

Instituto Adolfo Lutz (2004). Métodos físico-químicos para análise de alimentos. (4a ed.). Brasília: Ministério da Saúde.

International Coffee Organization (2019). World coffee production. Retrieved from http://www.ico.org/pt/ trade_statisticsp.asp

Kitzberger, C. S., Scholz, M. B. S., Pereira, L. F. P., \& Benassi, M. T. (2013). Composição química de cafés arábica de cultivares tradicionais e modernas. Pesquisa Agropecuária Brasileira, 48(11), 14981506. doi: 10.1590/S0100-204X2013001100011

Lima, T., Fº, Lucia, S. M. D., Saraiva, S. H., \& Lima, R. M. (2015). Características físico-químicas de bebidas de café tipo expresso preparadas a partir de blends de café arábica e conilon. Revista Ceres, 62(4), 333339. doi: 10.1590/0034-737X201562040001

MacFie, H. J., Bratchell, N., Greenhoff, K., \& Vallis, L. (1989). Designs to balance the effect of order of presentation and first-order carry-over effects in hall tests. Journal of Sensory Studies, 4(2), 129-148. doi: 10.1111/j.1745-459X.1989.tb00463.x
Martinez, H. E. P., Poltronieri, Y., Farah, A., \& Perrone, D. (2013). Zinc supplementation, production and quality of coffee beans. Revista Ceres, 60(2), 293299. doi: 10.1590/S0034-737X2013000200020

Monteiro, M. C., \& Trugo, L. C. (2005). Determinação de compostos bioativos em amostras comerciais de café torrado. Química Nova, 28(4), 637-641. doi: $10.1590 / \mathrm{S} 0100-40422005000400016$

Morais, S. A. L., Aquino, F. J. T., Nascimento, P. M., Nascimento, E. F., \& Chang, R. (2009). Compostos bioativos e atividade antioxidante do café conilon submetido a diferentes graus de torra. Química Nova, 32(2), 327-331. doi: 10.1590/S010040422009000200011

Perrone, A., Donangelo, C. M., \& Farah, A. (2008). Fast simultaneous analysis of caffeine, trigonelline, nicotinic acid and sucrose in coffee by liquid chromatography mass spectrometry. Food Chemistry, 110(4), 1030-1035. doi: 10.1016/j. foodchem.2008.03.012

Ribeiro, J. S., Ferreira, M. M. C., \& Salva, T. J. G. (2011). Chemometric models for the quantitative descriptive sensory analysis of arabica coffee beverages using near infrared spectroscopy. Talanta, 83(5), 13521358. doi: 10.1016/j.talanta.2010.11.001

Shan, J., Suzuki, T., Suhandy, D., Ogawa, Y., \& Kondo, N. (2014). Chlorogenic acid (CGA) determination in roasted coffee beans by Near Infrared (NIR) spectroscopy. Engineering in Agriculture, Environment and Food, 7(4), 139-142. doi: 10.1016/j.eaef.2014.08.003

Teixeira, O. R., Passos, F. R., \& Mendes, F. Q. (2016). Qualidade físico-química e microscópica de 14 marcas comerciais de café torrado e moído. Coffee Science, 11(3), 395-402. doi: 10.25186/cs.v11i3.1111

Toschi, T. G., Cardenia, V., Bonaga, G., Mandrioli, M., \& Rodriguez-Estrada, M. T. (2014). Coffee Silverskin: characterization, possible uses, and safety aspects. Journal of Agricultural and Food Chemistry, 62(44), 10836-10844. doi: 10.1021/jf503200z

Vicente, E., Ares, G., Rodríguez, G., Varela, P., Bologna, F., \& Lado, J. (2017). Selection of promising sweet potato clones using projective mapping. Journal of the Science of Food and Agriculture, 97(1), 158-164. doi: $10.1002 /$ jsfa. 7704 
